\title{
INFORMATION SYSTEM USAGE AND RISK MANAGEMENT AMONG ARABLE CROP FARMERS IN KWARA STATE, NIGERIA
}

\author{
O.A. OMOTESHO ${ }^{1}$, I.L. OLAGHERE ${ }^{*}$, F.S. DARAMOLA ${ }^{1}$, \\ A.H. ADENUGA ${ }^{2}$
}

^E-mail: ivieolaghere@gmail.com

Received: Mar. 09, 2020. Revised: Apr. 16, 2020. Accepted: Apr. 23, 2020. Published online: June 5, 2020

\begin{abstract}
Farmers need to be adequately informed in employing economic strategies to tackle risk situations in agriculture. This study sought to examine the risk management coping strategy employed by the farmers, explore determinants of risk management strategies, and to establish the relationship between information systems and risk management strategy employed. Primary data were used from 141 randomly selected farmers. Pre-tested interview schedule was used for data collection. Descriptive statistics, Likert-type scale, Multinomial logistic regression, and Bivariate correlation analysis were used for data analyses. The results revealed that the majority of the farmers were riskaverse. Gender of household head, the highest level of education attained, household size, farming experience and membership of association had a significant effect on the choice of coping strategies employed by the farmers.
\end{abstract}

Correlation results showed that the more access to information the farmers had to the different risks they encountered, the higher the management strategies they were likely to use. The study concludes that there is a significant relationship between information systems and risk management strategies employed. It was recommended that extension agents should be adequately sensitized on the various sources of information systems available to the farmers so that they can, in turn, pass the information to the farmers.

Keywords: bivariate correlation; crop production; information systems; Nigeria; risk planning.

\section{INTRODUCTION}

Agricultural growth in Nigeria is hindered by low productivity, diversification in production and

\footnotetext{
${ }^{1}$ Department of Agricultural Economics and Farm Management, University of Ilorin, P.M.B. 1515, Ilorin, Kwara State, Nigeria

${ }^{2}$ Agricultural and Food Economics Branch, Agri-Food and Biosciences Institute, Belfast, United Kingdom
} 
consumption basis, as well as a shrinking agrarian land base due to urbanization. These hindrances persist due to factors, like unpredictable weather conditions and price uncertainty. These factors have further increased risks in agricultural production and caused an unfavorable shock on productivity. Several studies have shown that the risks farmers face arise as a result of three leading causes, which are environmental variations causing production and yield uncertainties, price deviation creating market uncertainties, and inadequate information (Mittal, 2012; Ali, 2019). Arable crop farmers in Nigeria face many risks in their farming activities. For example, in the recent past, the country has recorded incidences of a flood, drought, crop diseases, pest infestation, as well as instability in prices of both farm produce and inputs. This has resulted in the variability of the farmers' yearly production. The risk situation is further complicated by the fact that these farmers operate in an environment with weak markets. The risks encountered by the farmers have a direct and immediate impact on local agricultural production, but it is germane to understand that their effects usually start from the farm, and goes all along the supply chain. Finding ways to mitigate against these risks has led to the farmers' quest for new technologies, knowledge, and information.

According to Falola and Adewumi (2013), arable crop farmers are low in their productivity due to the constraints they usually face in obtaining information from diverse sources.

The importance of information on agricultural productivity and risk management cannot be overlooked. Various studies (Chapman and Slaymakers, 2002; FAO, 2003; Asenso-Okyere and Mekonnen, 2012; Mittal, 2012) have shown that lack of market information on price demand indicators, and market logistics can result in a rise in production costs and increased transportation costs, which can also affect the revenue of the farmers. However, there have been changes over the years about the information system in agriculture in particular. This revolution is an intervention with the likelihood of ensuring that knowledge and information on cogent technologies, methods, and practices in agriculture are put into the right use by farmers (Stienen, 2007). Information and communication systems have become progressively more powerful tools for improving essential services and enhancing local development opportunities. Today, a new pattern of agricultural development is upcoming in both developing and developed counties. The application of information systems is making radical changes in production and marketing patterns (Agbetuyi and Oluwatayo, 2012; Stienen, 2007). The Nigerian Government, in her recognition of the importance of Information and Communication Technology (ICT) in enhancing knowledge, have started 


\section{O.A. OMOTESHO, I.L. OLAGHERE, F.S. DARAMOLA, A.H. ADENUGA}

the supply of essential infrastructure and training for the incorporation of ICT in the educational and agricultural sector. Information and communication systems in the agrarian industry facilitate knowledge sharing, especially within and among a variety of agricultural networks, including researchers, importers/ exporters, extension services, and farmers.

While it is true that the availability of proper and adequate information is needed to assess the risk faced by farmers, most studies in Nigeria have either tried to evaluate just the severity of the risks farmers face or the information systems used in agriculture. This study, however, goes further by checking the relationship between the information systems farmers have access to and the management strategy employed to mitigate against risks. Hence, this study, therefore, provided answers to the following research questions: a) What are the risk management strategies employed by farmers? b) What determines the risk management strategies used by the farmers? c) What is the relationship between the source of information used and risk management employed?

\section{MATERIALS AND METHODS}

To provide answers to the research questions, different analytical techniques were employed. Descriptive statistics were used to describe the various management strategies employed. Multinomial Logistic regression was employed to assess the determinants of the risk management strategies employed by farmers. Bivariate Correlation was used to show the relationship between information systems and risk management engaged in the study area.

The study was carried out in Kwara state, Nigeria. The state is located in the North-Central region of the country. It lies between latitudes $7^{\circ} 45^{\prime} \mathrm{N}$ and $9^{\circ} 30^{\prime} \mathrm{N}$ and longitudes $2^{\circ} 30^{\prime} \mathrm{E}$ and $6^{\circ} 25^{\prime} \mathrm{E}$, and it is characterized by two distinct seasons (the wet and dry seasons). The average daily temperature ranges between $21^{\circ} \mathrm{C}$ to $35^{\circ} \mathrm{C}$. The annual rainfall is between April and October, and it ranges between 1,000 and $1,500 \mathrm{~mm}$ (KWADP, 2014). The state has about 36,820 hectares of farmland, with an estimated figure of 260,528 farm families. The state was chosen for the study because it is predominantly agrarian, with agriculture employing more than $70 \%$ labour workforce. Arable crops grown in the state include rice, maize, yam, cassava, fruit, and leafy vegetables.

A three-stage sampling technique was used. In the first stage, the random selection of one local government area from each of the four Agricultural Development Zones was done. The next step involved a random selection of four communities from the selected local government area, while the last stage was the selection of ten farming households from a list of arable crop farming households in each selected communities, making sample size 160 . However, data for 141 households were used for analysis due to insufficient information given on the others. Data utilized were collected using a pretested interview schedule.

The multinomial logit regression model was used following Bayard et al. (2006) and Bandara and Thiruchelvam (2010) to express the probability of a farmer being in a particular category. The multinomial logit regression was used because the dependent variable has more 


\section{INFORMATION SYSTEM USAGE AND RISK MANAGEMENT AMONG ARABLE CROP FARMERS}

than two categories. The multinomial regression model, like all other regression models, is used to predict the outcome of the dependent or response variable given one or more independent variables. The use of the multinomial model assumes that the dependent variable is measured at a nominal level, and there must be one or more independent variables that are continuous, ordinal, or nominal.

$$
P_{(Y i=j)}=\frac{\exp (Y j X i)}{1+\sum_{j=0}^{4} \exp (Y j X i)} \quad \text { for } j=0,1,2,3,4
$$

Parameter estimates measure the impact of a unit increase in relevant explanatory variable on the log odds ratio of the particular state in relation to the base line category. The Multinomial Logit Model is explicitly expressed as:

$Y_{1}=\alpha_{1}+\beta_{11} X_{1}+\beta_{21} X_{2}+\ldots \ldots \ldots \ldots \ldots \beta_{n} X_{n}$ $+\varepsilon_{\mathrm{i} ;} Y_{2}=\alpha_{2}+\beta_{12} X_{1}+\beta_{22} X_{2}+\ldots \ldots \ldots \ldots \ldots .$. $\beta_{n} X_{n}+\varepsilon_{i} Y_{3}=\alpha_{3}+\beta_{13} X_{1}+\beta_{23} X_{2}+$ $\ldots \ldots \ldots \ldots \ldots \beta_{n} X_{n}+\varepsilon_{i} Y_{4}=\alpha_{4}+\beta_{14} X_{1}+$ $\beta_{24} X_{2}+\ldots \ldots \ldots \ldots \ldots \beta_{n} X_{n}+\varepsilon_{i} ; Y_{0}=\alpha_{0}+$ $\beta_{10} X_{1}+\beta_{20} X_{2}+\ldots \ldots \ldots \ldots \ldots \beta_{n} X_{n}+\varepsilon_{i}$ where, $Y \mathrm{i}$ represents five unordered categories of risk management strategies, which are: $Y_{1}=$ farmers that use Cooperatives; $Y_{2}=$ farmers that use Insurance; $Y_{3}=$ farmers that use Mixed Cropping System; $Y_{4}=$ farmers that employed Income diversification; $\mathrm{Y}_{0}=$ farmers that employed No risk

$$
r=\frac{\sum_{i=1}^{n}(x i-x)(y i-y)}{\sqrt{\sum_{i=1}^{n}(x i-x)^{2} \sum_{i=1}^{n}(y i-y)^{2}}}
$$

where, $r=$ correlation coefficient; $\mathrm{n}=$ number of observation across all groups; $\mathrm{x}=$ information system sources, and $\mathrm{y}=$ risk management strategies employed.

\section{RESULTS AND DISCUSSION}

The results of the data analysis done for the study are presented and discussed next.
The farmers were grouped into five categories based on risk management strategies mostly adopted in times of risk occurrence. These strategies adopted are No risk management strategy (put in God's hand), Income diversification, Mixed cropping, Use of insurance, and Membership of a cooperative.

The multinomial logit model for this study was stated as:

management strategy (which was the reference category)

The hypothesized independent variables were: $X_{1}=$ Duration of information usage (years); $X_{2}=$ Monthly income (naira); $X_{3}=$ Gender of the household head (male $=1$, female $=0$ ); $\mathrm{X}_{4}=$ Education level (number of years of successful schooling); $X_{5}=$ Age of household head (years); $X_{6}=$ Farm experience (years); $X_{7}=$ Member of any social group (yes $=1$, no $=0$ ); $\mathrm{X}_{8}=$ Farm size $(\mathrm{Ha}) ; X_{9}=$ Premium on insurance (naira); $\mathrm{X}_{10}=$ Mean cost of information system usage (naira).

The Bivariate Correlation was used to show the relationship between information systems and risk management employed, and was given as: 


\section{O.A. OMOTESHO, I.L. OLAGHERE, F.S. DARAMOLA, A.H. ADENUGA}

The reason for this is the geographical location of the state or the unstable weather conditions often experienced in the state, which has been attributed to the global climate changes currently being experienced. Aside from insufficient rainfall, the farmers also complained that the rains often did not come at the right time. Variations in the quantity of output produced ranked second, while the frequent outbreak of diseases ranked third among the risk situations faced by the farmers.

Table 1 - Distribution of the respondents according to the likelihood of risk occurrence

\begin{tabular}{|c|c|c|c|c|c|}
\hline \multirow[b]{2}{*}{ Risk source } & \multicolumn{5}{|c|}{ Level of occurrence } \\
\hline & $\begin{array}{c}\text { Often } \\
\text { freq (\%) }\end{array}$ & $\begin{array}{l}\text { Occasionally } \\
\text { freq }(\%)\end{array}$ & $\begin{array}{l}\text { Not at all } \\
\text { freq (\%) }\end{array}$ & Mean & Rank \\
\hline Insufficient rainfall & $79(56.1)$ & $47(33.3)$ & $15(10.6)$ & 2.45 & $1^{\text {st }}$ \\
\hline Variation in output & $58(41.1)$ & $66(46.8)$ & $17(12.1)$ & 2.30 & $2^{\text {nd }}$ \\
\hline Disease outbreak & $61(43)$ & $58(41.1)$ & $22(15.6)$ & 2.27 & $3^{\text {rd }}$ \\
\hline $\begin{array}{l}\text { Change in market price } \\
\text { of output }\end{array}$ & $48(34)$ & $78(55.4)$ & $15(10.6)$ & 2.23 & $4^{\text {th }}$ \\
\hline $\begin{array}{l}\text { Sudden change in the } \\
\text { price of input }\end{array}$ & $43(30.5)$ & $83(58.9)$ & $15(10.6)$ & 2.20 & $5^{\text {th }}$ \\
\hline Pest & $44(31.2)$ & $68(48.2)$ & $29(20.6)$ & 2.10 & $6^{\text {th }}$ \\
\hline Drought & $40(28.4)$ & $72(51.0)$ & $29(20.6)$ & 2.08 & $7^{\text {th }}$ \\
\hline Erosion & $42(29.8)$ & $41(29.1)$ & $58(41.1)$ & 1.89 & $8^{\text {th }}$ \\
\hline Reduction in soil quality & $22(15.6)$ & $53(37.6)$ & $66(46.8)$ & 1.69 & $9^{\text {th }}$ \\
\hline $\begin{array}{l}\text { Increase in the interest } \\
\text { rate of borrowed funds }\end{array}$ & $17(12.1)$ & $59(41.8)$ & $65(46.1)$ & 1.66 & $10^{\text {th }}$ \\
\hline $\begin{array}{l}\text { Change in government } \\
\text { policy }\end{array}$ & $9(6.4)$ & $62(44.0)$ & $70(49.6)$ & 1.57 & $11^{\text {th }}$ \\
\hline $\begin{array}{l}\text { Increase in premium } \\
\text { paid on insurance }\end{array}$ & $24(17.0)$ & $31(22.0)$ & $86(61.0)$ & 1.55 & $12^{\text {th }}$ \\
\hline Flood & $16(11.3)$ & $44(31.2)$ & $81(57.4)$ & 1.54 & $13^{\text {th }}$ \\
\hline $\begin{array}{l}\text { Restriction to the use of } \\
\text { certain pesticides/ } \\
\text { herbicides }\end{array}$ & $6(4.3)$ & $43(30.5)$ & $92(65.2)$ & 1.40 & $14^{\text {th }}$ \\
\hline
\end{tabular}

The economic importance and effect of prevalent disease occurrence cannot be overemphasized. This is because apart from the increase in the variable cost of the farmers, as a result of disease control measures, output of the farmers may be significantly reduced.

Other sources of risk that often occur to the farmers are changes in market output, a sudden change in the price of input, incidences of pest, erosion, and drought.

\section{Risk management strategies employed by the farmers}

For the provision of any support service to be of any significant benefit or impact to the farmer, the attitudes of the farmers towards risk must be known. By so doing, the reasons behind the risk management decisions 


\section{INFORMATION SYSTEM USAGE AND RISK MANAGEMENT AMONG ARABLE CROP FARMERS}

are clear. The different risk coping strategies employed by the farmers is presented next. Table 2 shows that variations in quantity produced rank first amongst the risks farmers are willing to use coping strategies.

Table 2 - Distribution of respondents according to risk management strategy employed

\begin{tabular}{|c|c|c|c|c|c|c|c|}
\hline \multirow[b]{2}{*}{$\begin{array}{l}\text { Risk } \\
\text { source }\end{array}$} & \multicolumn{7}{|c|}{ Coping strategies } \\
\hline & $\begin{array}{c}\text { No } \\
\text { coping } \\
\text { strate- } \\
\text { gy freq } \\
(\%)\end{array}$ & $\begin{array}{l}\text { Income } \\
\text { diversi- } \\
\text { fication } \\
\text { freq } \\
(\%)\end{array}$ & $\begin{array}{l}\text { Mixed } \\
\text { cro- } \\
\text { pping } \\
\text { freq } \\
(\%) \\
\end{array}$ & $\begin{array}{l}\text { Coope- } \\
\text { rative } \\
\text { society } \\
\text { freq } \\
(\%)\end{array}$ & $\begin{array}{l}\text { Insu- } \\
\text { rance } \\
\text { freq } \\
(\%)\end{array}$ & Mean & $\mathbf{R}$ \\
\hline $\begin{array}{l}\text { Variation in } \\
\text { quantity produced }\end{array}$ & $\begin{array}{c}27 \\
(19.2) \\
\end{array}$ & $\begin{array}{c}58 \\
(41.1) \\
\end{array}$ & $\begin{array}{c}27 \\
(19.2)\end{array}$ & $\begin{array}{c}24 \\
(17.0) \\
\end{array}$ & $\begin{array}{c}5 \\
(3.5)\end{array}$ & 2.49 & $1^{\text {st }}$ \\
\hline Incidence of pest & $\begin{array}{c}35 \\
(24.8)\end{array}$ & $\begin{array}{c}57 \\
(40.5)\end{array}$ & $\begin{array}{c}22 \\
(15.6)\end{array}$ & $\begin{array}{c}11 \\
(7.8)\end{array}$ & $16(11.3)$ & 2.40 & $2^{\text {nd }}$ \\
\hline $\begin{array}{l}\text { Sudden change in } \\
\text { the price of inputs }\end{array}$ & $\begin{array}{c}30 \\
(21.2)\end{array}$ & $\begin{array}{c}27 \\
(19.2)\end{array}$ & $\begin{array}{c}50 \\
(35.5)\end{array}$ & $\begin{array}{c}31 \\
(22.0)\end{array}$ & $\begin{array}{c}3 \\
(2.1)\end{array}$ & 2.18 & $3^{\text {rd }}$ \\
\hline Diseases & $\begin{array}{c}29 \\
(20.6)\end{array}$ & $\begin{array}{c}20 \\
(14.2)\end{array}$ & $\begin{array}{c}44 \\
(31.2)\end{array}$ & $\begin{array}{c}11 \\
(7.8)\end{array}$ & $37(26.2)$ & 2.11 & $4^{\text {th }}$ \\
\hline $\begin{array}{l}\text { Change in market } \\
\text { price of output }\end{array}$ & $\begin{array}{c}26 \\
(18.4)\end{array}$ & $\begin{array}{c}30 \\
(21.3) \\
\end{array}$ & $\begin{array}{c}40 \\
(28.4) \\
\end{array}$ & $\begin{array}{c}41 \\
(29.1)\end{array}$ & $\begin{array}{c}4 \\
(2.8) \\
\end{array}$ & 2.11 & $4^{\text {th }}$ \\
\hline Insufficient rainfall & $\begin{array}{c}86 \\
(61.0) \\
\end{array}$ & $\begin{array}{c}29 \\
(20.6)\end{array}$ & $\begin{array}{c}24 \\
(17.0)\end{array}$ & $\begin{array}{c}2 \\
(1.4)\end{array}$ & $\begin{array}{c}0 \\
(0.0)\end{array}$ & 2.04 & $6^{\text {th }}$ \\
\hline $\begin{array}{l}\text { Reduction in soil } \\
\text { quality }\end{array}$ & $\begin{array}{c}68 \\
(48.2)\end{array}$ & $\begin{array}{c}22 \\
(15.6)\end{array}$ & $\begin{array}{c}45 \\
(31.9)\end{array}$ & $\begin{array}{c}6 \\
(4.3)\end{array}$ & $\begin{array}{c}0 \\
(0.0)\end{array}$ & 1.89 & $7^{\text {th }}$ \\
\hline $\begin{array}{l}\text { Change in } \\
\text { government policy }\end{array}$ & $\begin{array}{c}54 \\
(38.2) \\
\end{array}$ & $\begin{array}{c}57 \\
(40.5) \\
\end{array}$ & $\begin{array}{c}10 \\
(7.1) \\
\end{array}$ & $\begin{array}{c}20 \\
(14.2) \\
\end{array}$ & $\begin{array}{c}0 \\
(0.0) \\
\end{array}$ & 1.80 & $8^{\text {th }}$ \\
\hline Drought & $\begin{array}{c}60 \\
(42.6)\end{array}$ & $\begin{array}{c}52 \\
(36.9)\end{array}$ & $\begin{array}{c}11 \\
(7.8)\end{array}$ & $\begin{array}{c}14 \\
(9.9)\end{array}$ & $\begin{array}{c}4 \\
(2.8)\end{array}$ & 1.67 & $9^{\text {th }}$ \\
\hline Erosion & $\begin{array}{c}47 \\
(33.3) \\
\end{array}$ & $\begin{array}{c}48 \\
(34.0) \\
\end{array}$ & $\begin{array}{c}23 \\
(16.3) \\
\end{array}$ & $\begin{array}{c}6 \\
(4.3) \\
\end{array}$ & $17(12.1)$ & 1.66 & $10^{\text {th }}$ \\
\hline Flood & $\begin{array}{c}52 \\
(36.9)\end{array}$ & $\begin{array}{c}35 \\
(24.8) \\
\end{array}$ & $\begin{array}{c}22 \\
(15.6)\end{array}$ & $\begin{array}{c}7 \\
(5.0) \\
\end{array}$ & $25(17.7)$ & 1.38 & $11^{\text {th }}$ \\
\hline $\begin{array}{l}\text { Increase in the } \\
\text { interest rate of } \\
\text { borrowed funds }\end{array}$ & $\begin{array}{c}47 \\
(33.3)\end{array}$ & $\begin{array}{c}20 \\
(14.2)\end{array}$ & $\begin{array}{c}17 \\
(12.1)\end{array}$ & $\begin{array}{c}53 \\
(37.6)\end{array}$ & $\begin{array}{c}4 \\
(2.8) \\
\end{array}$ & 1.36 & $12^{\text {th }}$ \\
\hline $\begin{array}{l}\text { Increase in } \\
\text { premium paid to an } \\
\text { insurance }\end{array}$ & $\begin{array}{c}98 \\
(69.5)\end{array}$ & $\begin{array}{c}10 \\
(7.1)\end{array}$ & $\begin{array}{c}7 \\
(5.0)\end{array}$ & $\begin{array}{c}25 \\
(17.7)\end{array}$ & $\begin{array}{c}1 \\
(0.7)\end{array}$ & 0.79 & $13^{\text {th }}$ \\
\hline $\begin{array}{l}\text { Restriction to } \\
\text { use of certain } \\
\text { pesticides/ } \\
\text { herbicides }\end{array}$ & $\begin{array}{c}106 \\
(75.2)\end{array}$ & $\begin{array}{c}21 \\
(14.9)\end{array}$ & $\begin{array}{c}0 \\
(0.0)\end{array}$ & $\begin{array}{c}12 \\
(8.5)\end{array}$ & $\begin{array}{c}2 \\
(1.4)\end{array}$ & 0.55 & $14^{\text {th }}$ \\
\hline $\begin{array}{l}\text { Average } \\
\text { percentage (\%) }\end{array}$ & 38.75 & 24.62 & 17.32 & 13.32 & 5.99 & & \\
\hline Rank & $1^{\text {st }}$ & $2^{\text {nd }}$ & $3^{\text {rd }}$ & $4^{\text {th }}$ & $5^{\text {th }}$ & & \\
\hline
\end{tabular}


This is because the differences in the amount produced in most cases were a reduction in the farmers' output. The farmers in the study area mostly resulted in income diversification as a coping strategy for this risk. Income diversification meant that they engaged in other incomegenerating activities apart from farming activities. This agrees with the findings of Fashogbon and Oni (2013), as well as that of Reardon (1997), that most farmers in Africa usually resort to income diversification as a means of reducing the risk associated with farming, especially in situations where there is a reduction in output or some cases when there is total crop loss. Incidences of the occurrence of pest outbreaks and the sudden change in the prices of farm inputs ranked second and third, respectively, among the risks the farmers sought coping strategies. The use of insurance as a coping strategy ranked the least. This buttresses evidence shown by Surminski (2014) that even though the use of insurance to militate against risk has generally increased, farmers have still not fully embraced the idea.

Furthermore, figures from the Department of International Development show that in developing countries, only $5 \%$ of direct natural disaster losses are insured, compared to $40 \%$ in developed countries (DFID, 2013). Overall, the modal category of the risk coping strategy employed by the farmers was that of no coping strategy used. This means that the farmers mostly depended on their "gods" to help manage the risks they encountered. This finding collaborates with studies of Ali (2019) and Fashogbon and Oni (2013) that most small scale farmers are risk-averse.

\section{Factors determining risk management strategies among the farmers}

This sub-section discusses the various factors that determined the usage of the different coping strategies among farmers.

The results of the multinomial logistic regression established that at least one of the hypothesized variables included in the model was significantly different from zero, as indicated by the chi-square value of 142.80 and the value of $\mathrm{P}^{2}=0.001$. The factors that influence the choice of management strategy employed are presented on Table 3. It shows that the mean years spent on information used in support of farming activities significantly affect the choice of selecting cooperative as a risk management strategy by farmers, compared to not adopting any coping strategy. The log odd value implies that an increase in years of information usage by one year increased the probability of choosing cooperative society measures by 0.27 , while keeping all other variables constant. This could be because the farmers have access to reliable information at the cooperatives. Thus, the longer time farmers access and use information from sources, such as 
extension agents, friends and family, radio, and mobile phones for farming activities, the higher their willingness to manage risk by being a member of a cooperative society.

The positive and significant coefficient of gender for all the categories implies that the probability of men remaining in the comparison category relative to the reference category increases as the variable increases.

This is probably because studies by Bempoma and Acquah (2014) and Odendo et al. (2009) have shown that male farmers have more access to extension service and information, compared to their female counterparts. Thus, they can harness the information gotten and take practical steps to adopt innovations and technologies to militate against risks in their businesses. At the 5\% level of significance, the education level influenced the choice of the use of insurance by the farmers in managing risk.

The log odd for the level of education indicates that a one-unit increase in the years of education increases the probability of the farmers remaining in the comparison category relative to the reference category by a factor of about 1.27 if all else is held constant. This may be attributed to the fact that farmers with more education can access and comprehend information on the need to transfer risk through the use of insurance (Thuong and Pabuayon, 2015).

Table 3 - Determinants of the choice of risk management strategies among the farmers

\begin{tabular}{|c|c|c|c|c|}
\hline & Category 1 & Category 2 & Category 3 & Category 4 \\
\hline Variables & $\begin{array}{c}\text { Coefficient } \\
\text { (Z value) }\end{array}$ & $\begin{array}{c}\text { Coefficient } \\
\text { (Z value) }\end{array}$ & $\begin{array}{l}\text { Coefficient } \\
\text { (Z value) }\end{array}$ & $\begin{array}{c}\text { Coefficient } \\
\text { (Z value) }\end{array}$ \\
\hline $\begin{array}{l}\text { Duration of } \\
\text { information usage }\end{array}$ & $\begin{array}{l}0.266^{\star \star} \\
(2.16)\end{array}$ & $\begin{array}{l}-0.137 \\
(-0.88)\end{array}$ & $\begin{array}{l}0.076 \\
(0.61)\end{array}$ & $\begin{array}{l}0.168 \\
(1.46)\end{array}$ \\
\hline Gender & $\begin{array}{l}2.850^{* *} \\
(2.53)\end{array}$ & $\begin{array}{l}3.996^{* *} \\
(3.32)\end{array}$ & $\begin{array}{l}2.641^{* *} \\
(2.55)\end{array}$ & $\begin{array}{l}2.155^{\star *} \\
(2.41)\end{array}$ \\
\hline Education level & $\begin{array}{l}-0.026 \\
(-0.07) \\
\end{array}$ & $\begin{array}{l}1.269^{* \star} \\
(2.12)\end{array}$ & $\begin{array}{l}0.394 \\
(1.05) \\
\end{array}$ & $\begin{array}{l}-0.304 \\
(-0.89) \\
\end{array}$ \\
\hline Household size & $\begin{array}{l}0.498 \\
(1.57) \\
\end{array}$ & $\begin{array}{l}0.705^{* *} \\
(1.98)\end{array}$ & $\begin{array}{l}1.020^{* *} \\
(3.23)\end{array}$ & $\begin{array}{l}0.467 \\
(1.63) \\
\end{array}$ \\
\hline Farming experience & $\begin{array}{l}-0.076 \\
(-1.23)\end{array}$ & $\begin{array}{l}-0.016 \\
(-0.25)\end{array}$ & $\begin{array}{l}-0.020 \\
(-0.34)\end{array}$ & $\begin{array}{l}-0.102^{* *} \\
(-1.78)\end{array}$ \\
\hline $\begin{array}{l}\text { Member of farming } \\
\text { association }\end{array}$ & $\begin{array}{l}-1.964^{\star *} \\
(-1.86)\end{array}$ & $\begin{array}{l}1.497 \\
(0.98)\end{array}$ & $\begin{array}{l}-1.802^{* \star} \\
(-1.70)\end{array}$ & $\begin{array}{l}-0.421 \\
(-0.41)\end{array}$ \\
\hline Constant & $\begin{array}{l}-9.923^{\star *} \\
(-2.76)\end{array}$ & $\begin{array}{l}-17.372^{\star \star} \\
(-3.08)\end{array}$ & $\begin{array}{l}-11.220^{\star *} \\
(-3.14)\end{array}$ & $\begin{array}{l}-4.438 \\
(0.132)\end{array}$ \\
\hline
\end{tabular}

Log likelihood $=-152.16$; LR Chi-square $(22)=142.80^{* *} ;$ Pro $>$ Chi-square $=0.001$;

Pseudo $R^{2}=0.3223 ;{ }^{* *}=$ Significant at $5 \%$ level of probability 
The influence of household size as a factor that determines the choice of farmers in risk management strategies was significant for insurance and mixed cropping. The value of the coefficient shows that as household size increases by one person, the probability of engaging in mixed cropping as a coping strategy rises by about 0.71 . This might be so due to the positive correlation between larger household size and availability of labour for the various farming activities they may be involved with.

The negative multinomial logit coefficient of farming experience implies that if the farmers were to increase this variable by one unit, the relative risk for the use of income diversification as a coping strategy relative to the use of no coping strategy would be expected to decrease by 0.10 . This may be that the farmers might have tried diverting their income to other production activities in times past, which ultimately brought no better result, therefore, discouraging their interest in such strategy.

Similarly, being a member of the farming association increased the chances of the farmers that employed the use of cooperatives and mixed farming methods as coping strategies to move to the reference category. This finding agrees with that of Yakubu et al. (2013). This may be because the information receives from such associations has not been adequately harnessed and utilized. It may also be that the farming associations have not been able to convince the farmers about the benefits that they stand to derive from participation in cooperatives and to engage in mixed crop farming as a coping strategy.

\section{Relationship between information source and risk management strategies adopted}

In the study area, extension agents were the most common source of information concerning the risk management strategy to employ by the farmers. The farmers alluded to the fact that most of the information gotten on risk coping strategies were from extension agents. This was followed by news from family and then friends and radio programs. Others were from television, mobile telephones, and the internet, in that order. The strength of the relationship between the information received by farmers and the risk management strategy used is shown in Table 4.

The result showed that the relationship is significant at $1 \%$ level. The implication of this is that the more available the information relating to risk management is to farmers, the higher the probability that the farmers will make use of insurance as a coping strategy. As already seen in Table 2, the use of insurance as a coping strategy was the least employed. Only about $6 \%$ of the farmers secured their production using insurance. This is probably because the farmers are not adequately informed about the benefits that they can get from the use of insurance. 
They are more focused on the seeming loss of the insurance premiums paid if all goes well during the production season. The smallscale farmer sees the insurance premiums as additional production costs. However, the strength of the relationship is weak, which shows room for improvement by the farmers to increase their contact with information sources for relevant and reliable information for increased productivity and employment of adequate risk management strategies.

Table 4 - Correlation analysis between information system and risk management

\begin{tabular}{lcc}
\hline & $\begin{array}{c}\text { Information } \\
\text { system }\end{array}$ & $\begin{array}{c}\text { Risk management } \\
\text { strategy }\end{array}$ \\
\hline Information system & 1 & $0.371^{* \star *}$ \\
\hline Pearson correlation & 141 & 0.01 \\
\hline Sig. (2-tailed) & & 141 \\
\hline $\mathrm{N}$ & $0.371^{* * *}$ & 1 \\
\hline Risk management strategy & 0.00 & 141 \\
\hline Pearson correlation & 141 &
\end{tabular}

\section{CONCLUSION AND RECOMMENDATIONS}

The study concluded that insufficient rainfall was the riskest situation faced by the farmers, and income diversification was the most typical strategy employed by the farmers who used risk coping strategies.

However, there was a significant relationship between information use and risk management strategies applied. Therefore, extension agents should be adequately sensitized on the suitability of the various coping strategies so that they can pass the information to farmers.

Also, farmers need to be encouraged to belong to associations and cooperatives to have access to adequate and reliable information. Furthermore, efforts should also be made by the government to make agricultural insurance attractive to the farmers by ensuring that safety net programs that are created for the farmers remain functional.

\section{REFERENCES}

Agbetuyi, P.A. \& Oluwatayo, J.A. (2012). Information and communication technology (ICT) in the Nigerian education system. Mediterr.J.Soc.Sci., 3(3): 41-45, DOI: $10.5901 / \mathrm{mjss} .2012 . v 3 n 3 p 41$

Ali, E. (2019). Farmers' attitudes towards climate risks and effects of farmers' risk aversion behavior on inputs use in Northern Togo. Sarhad J.Agric., 35(3): 663-674, DOI: 10.17582/ journal.sja/2019/35.3.663.674

Asenso-Okyere, K. \& Mekonnen, D.A. (2012). The importance of ICTs in the provision of information for improving agricultural productivity and rural incomes in Africa. Working 


\section{O.A. OMOTESHO, I.L. OLAGHERE, F.S. DARAMOLA, A.H. ADENUGA}

Paper; UNDP, Regional Bureau for Africa, WP 2012-015, $30 \mathrm{p}$.

Bandara, D.G.V.L. \& Thiruchelvam, S. (2010). Factors affecting the choice of soil conservation practices adopted by potato farmers in Nuwara Eliya District, Sri Lanka. Trop.Agric.Res.Ext., 1: 49-54, DOI: 10.4038/tare.v11i0.1789

Bempomaa, B. \& Acquah, H.D. (2014). Technical efficiency analysis of maize production: evidence from Ghana. APSTRACT: Applied Studies in Agribusiness and Commerce, AGRIMBA, 8 (2-3): 1-7, DOI: 10.22004/ag.econ.202884

Bayard, B., Jolly, C.M. \& Shannon, D.A. (2006). The adoption and management of soil conservation practices in Haiti: the case of rock walls. Agric.Econ.Rev., 7(2): 1-12, DOI: 10.22004/ag.econ.44111

Chapman, R. \& Slaymaker, T. (2002). ICTs and rural development: Review of literature, current interventions and opportunities for action. Working paper 192, Overseas Development Institute (ODI), London, U.K., pp. 136.

DFID (2013). Helping developing countries deal with humanitarian emergencies. Department for International Development: London. Available at: https://www.gov.uk/government/polic ies/helping-developing-countriesdeal-with-humanitarian-emergencies / supporting-pages/ helping-countries -protect-themselves-against-futuredisasters

Falola, A. \& Adewumi, M.O. (2013). Impact of mobile telephony on technical efficiency of farmers in Nigeria. JSDA, 15(6): 86-100.

Fashogbon, A.E. \& Oni, O.A. (2013). Food poverty and livelihood issues in rural Nigeria. AFJARE, 8(2): 108135, DOI: 10.22004/ag.econ.160631
Food and Agricultural Organization (2003). FAO and ICT in Agriculture, Rome.

Kwara Agricultural Development Project (KWADP) (2014). Annual Report, Kwara ADP, Ilorin, Nigeria.

Mittal, S. (2012). Modern ICT for agricultural development and risk management in smallholder agriculture in India. Socioeconomics Working, Paper 3. Mexico, D.F.: CIMMYT.

Odendo, M., Obare, G.A. \& Salasya, B. (2009). Factors responsible for differences in uptake of integrated soil fertility management practices amongst smallholders in western Kenya. Afr.J.Agric.Res., 4(11): 13031311.

Reardon, T. (1997). Using evidence of household income diversification to inform study of the rural nonfarm labour market in Africa. World Development, 25(5): 735-747, DOI: 10.1016/S0305-750X(96)00137-4

Stienen, J. (2007). How ICT can make a difference in agricultural livelihoods. www.agris.fao.org.

Surminski, S. (2014). The role of insurance in reducing direct risk - the case of flood insurance. International Rev.Environ.Res.Econ. , 7(3-4): 241-278, DOI: 10.1561/101.000000 62

Thuong, T.T. \& Pabuayon, I.M. (2015). Factors affecting the storage decision of onion farmers in Kinh Mon District, Hai Duong Province, Vietnam. JEMAD, 1(1): 15-27.

Yakubu, D.H., Abubakar, B.Z., Atala, T.K. \& Muhammed, A. (2013). Use of information and communication technologies among extension agents in Kano State, Nigeria. J.Agric.Ext., 17(1): 162-173, DOI: 10.4314/jae.v17i1.16. 